\title{
Prevalence and distribution of most common ICU pathogens in a Thai-university hospital during a 5 -year period
}

\author{
S Boonsong *, P Chongtrakool, S Srisangkaew, P Santanirand
}

From International Conference on Prevention \& Infection Control (ICPIC 2011)

Geneva, Switzerland. 29 June - 2 July 2011

\section{Introduction / objectives}

Nosocomial infection remains a major problem among ICU patients which may lead to lethal outcome. Data analysis of prevalence and antibiotic resistance profile of bacterial isolates from ICU could help improvement of treatment, control and prevention of infection.

\section{Methods}

Microbiological data during year 2006-2010 of Ramathibodi Hospital, a 900-bed Thai-University hospital in Bangkok, Thailand, were retrospective analysed. All bacterial isolates were identified by conventional biochemical tests as recommended in Manual of Clinical Microbiology. Candida species were identified according to characteristics of chlamydoconidia production and carbohydrate assimilation/fermentation profile using 13/ 6 carbon substrates.

\section{Results}

From year 2006 to 2010, the main nosocomial pathogens in the ICU were Candida albicans $(16.9 \%, 17 \%$, $18.2 \%, 19.4 \%$ and $19.5 \%$ respectively), followed by nonfermentative gram negative bacilli either $P$. aeruginosa $(11.3 \%, 12 \%, 12.2 \%, 15.3 \%, 14.3 \%$ respectively) or $A$. baumannii $(12 \%, 11.3 \%, 14.7 \%, 13.1 \%, 17.7 \%$ respectively) or Staphylococcus coagulase-positive (10.7\%, $11.75 \%, 9.45 \%, 10.3 \%, 7.6 \%)$. The second most common gram-negative bateria were either Escherichia coli (8.1\%, $8.5 \%, 6.4 \%, 6.8 \%, 8.0 \%)$ or Klebsiella pneumoniae $(7.5 \%$, $6.9 \%, 7.9 \%, 6.6 \%, 8 \%)$ which approximately half of them were ESBL producers.

Department of pathology, Ramathibodi Hospital, Mahidol University, Bangkok, Thailand

\section{Conclusion}

In last 5-year period, the prevalence of nosocomial infection by $C$. albicans and A. baumannii in our ICU is rising, while the prevalence of ESBL-producing bacilli is quite stable. The same incidents were reported by many hospitals worldwide. This may be due to the change in preference of antimicrobial agents used by clinician which need further analysis.

\section{Disclosure of interest}

None declared.

Published: 29 June 2011

doi:10.1186/1753-6561-5-S6-P244

Cite this article as: Boonsong et al:: Prevalence and distribution of most common ICU pathogens in a Thai-university hospital during a 5-year period. BMC Proceedings 2011 5(Suppl 6):P244.

Submit your next manuscript to BioMed Central and take full advantage of:

- Convenient online submission

- Thorough peer review

- No space constraints or color figure charges

- Immediate publication on acceptance

- Inclusion in PubMed, CAS, Scopus and Google Scholar

- Research which is freely available for redistribution

Submit your manuscript at Submit your manuscript at
www.biomedcentral.com/submit C Biomed Central

\section{( Biomed Central}

(c) 2011 Boonsong et al; licensee BioMed Central Ltd. This is an open access article distributed under the terms of the Creative Commons Attribution License (http://creativecommons.org/licenses/by/2.0), which permits unrestricted use, distribution, and reproduction in any medium, provided the original work is properly cited. 